\title{
Recycling of Ornamental Stones Hazardous Wastes
}

\author{
Abdel Monem Soltan, Zeinab Taman, Baher El-Kaliouby \\ Geology Department, Faculty of Science, Ain Shams University, Cairo, Egypt. \\ Email: abdelmonemsoltan@gmail.com
}

Received September 11 ${ }^{\text {th }}, 2011$; revised October $10^{\text {th }}, 2011$; accepted October $20^{\text {th }}, 2011$.

\begin{abstract}
Sawing and polishing of the ornamental stones always generate large amount of solid and wet hazardous wastes, which pollute the environment. In Shak Al-Thoaban area, East Cairo, Egypt, huge amounts of these wastes were accumulated, during the last years, as rejects "Solid" and wet "Sahala" wastes, representing one of the main sources of environmental pollution. The aim of this work is to characterize and evaluate these wastes for recycling in quicklime production. Hence, samples of both wastes were investigated for their chemical and mineral composition applying XRF, XRD, DTA and TGA methods. Free lime content and reactivity $\left(R_{D I N}\right)$ of both samples were also determined after calcination for differnt soaking times $(0.25-2.0 \mathrm{~h})$ at $1000^{\circ} \mathrm{C}$. The results were interpreted in relation to composition and microstructure of the fired samples as revealed by TLM and SEM methods. The $R_{D I N}$ reactivity of the resulted lime is changeable along soaking time at $100{ }^{\circ} \mathrm{C}$ because of the microfabric of its crystallites. The lime of the "Solid" sample is preserving the original limestone microstructure that contributes in its higher $R_{D I N}$ reactivity values at all soaking times. The relatively higher degree of grain growth of lime crystallites in the "Sahala" sample leads to its lower reactivity. The optimum soaking times for the highest lime reactivity are 0.25 and $1 \mathrm{~h}$ for the "Solid" and "Sahala" samples, respectively. On increasing soaking time up to $2 \mathrm{~h}$, both samples show minimum $R_{\text {DIN }}$ values. The "Solid" sample also gives higher free lime content than the "Sahala" one at all soaking times. It is gradually increased in the former sample up to a maximum ( $96 \%$ - 97\%) on increasing soaking time up to $1-2 \mathrm{~h}$. On the other side, a maximum free lime ( $95 \%)$ is detected in "Sahala" sample at $0.25 \mathrm{~h}$ soaking time and gradually decreased to (87\%) up to $2 \mathrm{~h}$.
\end{abstract}

Keywords: Recycling, Ornamental Stones, Wastes, Microstructure, Quicklime

\section{Introduction}

Development of the ornamental stone industry in Egypt is related to the expansion in the building and construction sector in the last three decades [1,2]. Most of the ornamental stone factories are located in Shak Al-Thoaban area, Katameya, East Cairo, Egypt.

The quarrying, sizing and polishing of the limestone, granite, marble rocks among others are the main processes for ornamental stone production. Through these processes $20 \%-30 \%$ of the sawed blocks become fine powder and solid-cutting rejects [3]. The solid-reject wastes cause dangerous effects on the people working conditions if stacked carelessly, however, the land filling is costly and has serious drawbacks. Also, the fine powder can cause serious health problems on inhalation and ecological problems, when mixed with water and poured into the natural water resources, such as rivers and channels $[4,5]$.
Recycling of the ornamental stone wastes is the best way for eliminating their hazardous impact on the people and environment. This is encouraged by the fact that these waste materials are mainly rock-derived with high purity and can be consequently incorporated in different industries [6].

Many possible applications were suggested to incurporate proportions of the wastes in the processing of tiles [7-12], red ceramics [13-16], building materials [17], mortars [18], concrete aggregates and mixtures $[6,19]$ and clay products [20,21].

According to the author's knowledge, no research works were directed to recycling of the solid rejects and wet-powder "Sahala" wastes as a source of quicklime after calcination. Therefore, this work directly aims at recycling both of these ornamental stone wastes accumulated in Shak Al-Thoaban area for production of reactive quicklime. Hence, samples of both wastes were investigated for their chemical and mineral composition apply- 
ing XRF, XRD, DTA and TGA methods. Free lime content and reactivity $\left(\mathrm{R}_{\mathrm{DIN}}\right)$ of both samples were also determined after calcination for different soaking times $(0.25-2.0 \mathrm{~h})$ at $1000^{\circ} \mathrm{C}$. The results were interpreted in relation to composition and microstructure of the fired samples as revealed by TLM and SEM methods.

\section{Sampling and Experimental Procedure}

In Shak Al-Thoaban area, when the rock fine-powder is mixed with water during sawing and polishing it transforms into aqueous sludge called "Sahala", whereas the rejects of rock-cuttings is called "Solid" wastes and both are disposed in the surrounding environment (Figures 1 and 2). Representative samples of both wastes were collected and prepared through many field trips to the area.

The "Solid" sample was crushed into grains of 5 - 10 $\mathrm{mm}$ in diameter. The average mineral content of the two samples was determined by conducting X-ray diffraction analysis (XRD) using a Philips X-ray diffractometer (Model PW/1840) with a Ni-Filtered, $\mathrm{Cu}-\mathrm{K} \alpha$ radiation $(\lambda$ $=1.542 \AA$ ). The thermal behaviour was revealed by thermal analysis, adopting a simultaneous recording of variations in heat content and weight by differential-thermal

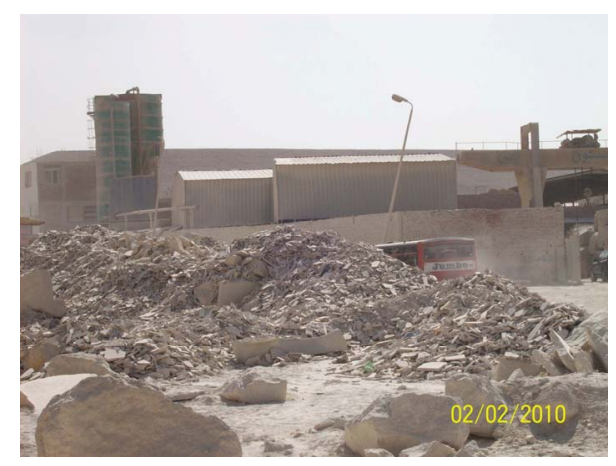

Figure 1. "Solid” wastes of Shak Al-Thoaban.

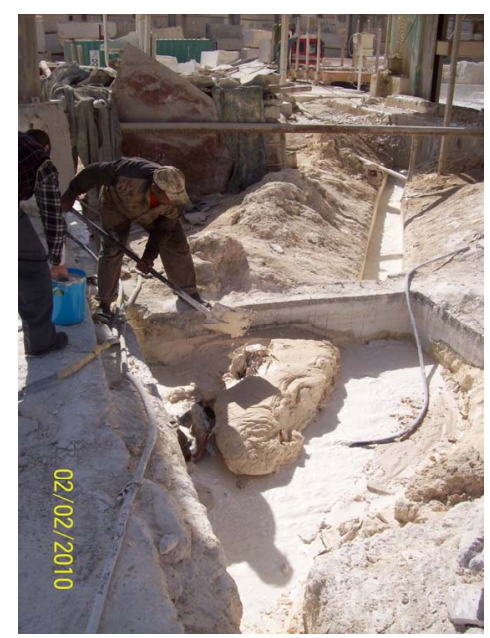

Figure 2. "Sahala” wastes of Shak Al-Thoaban. and thermo-gravimetric analyses (DTA and TGA) methods, respectively. The thermograms of both analyses are recorded as a function of temperature, with a rate of heating of $10^{\circ} \mathrm{C} / \mathrm{min}$, using Perkin Elmer, 7 series Thermal Analysis System. The chemical composition was determined by X-ray fluorescence (XRF) using a spectrometer (Model PW/1404) with Rh target and six analyzing crystals. The petrographic characteristics of the "Solid" sample were examined using transmitted light (TLM) and scanning electron microscopy (SEM).

Firing of the "Solid" and "Sahala" waste samples was conducted by loading in alumina boats which calcined in an electrical muffle furnace at $1000^{\circ} \mathrm{C}$ for $0.25,0.5,1$ and $2 \mathrm{~h}$ soaking times. After each firing, the calcined samples were investigated for their microfabric by SEM as well as free lime content and reactivity. The lime samples were dissolved in a sugary solution and titrated against standardized $\mathrm{HCl}$ solution for determination of freelime content [22]. The lime reactivity was measured in terms of the $R_{\text {DIN }}$ values [23], where the lime grains were mixed with distilled water ( 1 lime: 4 water) in a calorimeter. The time elapsed to attain a temperature of $60^{\circ} \mathrm{C}$ (T60 sec.) was measured and the $\mathrm{R}_{\mathrm{DIN}}$ was calculated from the equation: $\mathrm{R}_{\mathrm{DIN}}=2400 / \mathrm{T} 60$.

\section{Results and Discussion}

The XRD analysis showed that the main mineral content of both of the "Solid" and "Sahala" waste samples is the calcite $\left(\mathrm{CaCO}_{3}\right)$ together with minor gypsum $\mathrm{CaSO}_{4} \cdot 2 \mathrm{H}_{2} \mathrm{O}$ in the "Sahala" sample. The DTA and TG curves (Figure 3) confirm the presence of calcite, where the its decomposition commences at $\sim 670^{\circ} \mathrm{C}, 720^{\circ} \mathrm{C}$ and ends at $\sim 1000^{\circ} \mathrm{C}$ with an average weight loss of $43.63 \%$ and

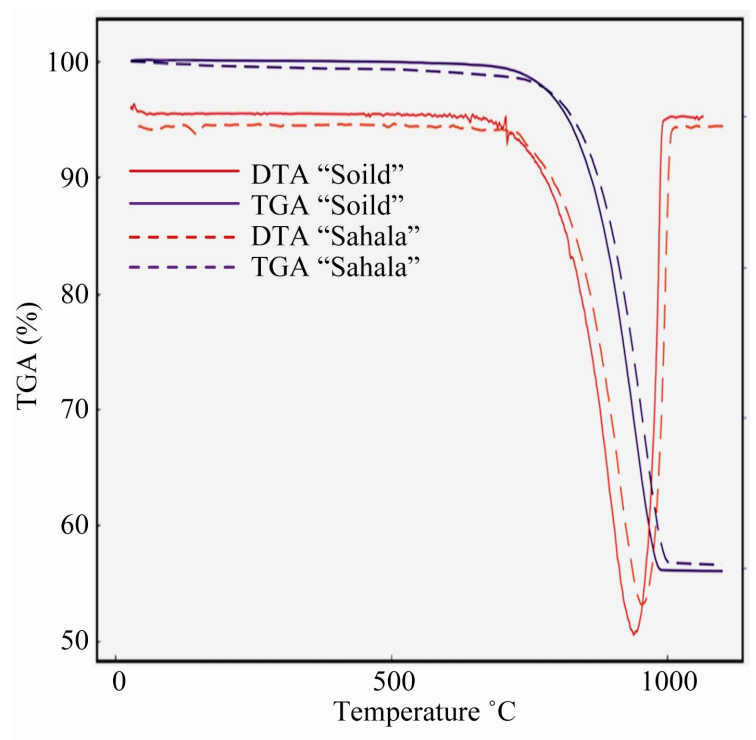

Figure 3. DTA and TGA of the waste samples. 
$42.02 \%$ in the "Solid" and "Sahala" samples, respectively [24]. The minor amount of gypsum detected by $\mathrm{XRD}$ in the latter sample is confirmed by a small endothermic peak at $\sim 140^{\circ} \mathrm{C}$ and a weight loss of $\sim 1.2 \%$ due to its dehydroxylation.

The chemical composition of the two waste samples (Table 1) indicates highly pure material suitable for the lime production [25]. The $\mathrm{CaO}$ average is $55.23 \%$, whereas the average of total impurity oxides (sum of silica, alumina, magnesia as well as iron and alkali oxides) is $0.60 \%$. Also, TLM-microstructure of the "Solid" sample is showing the enrichment of fossils (grain-supported) with prominent pores as exhibited in (Figure 4).

Figure 5 shows the trends of free lime content and

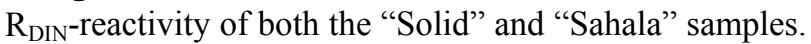
In the "Solid" lime samples the free lime content increases with soaking time up to a maximum $(\sim 97 \%)$ at 1 h. and slightly decreases to $(\sim 96 \%)$ at $2 \mathrm{~h}$. However, the "Sahala" free lime is maximized at $0.25 \mathrm{~h}(\sim 95 \%)$, then gradually decreased to a minimum at $2 \mathrm{~h}(\sim 87 \%)$. The decrease in lime content is due to the possible belite formation with the longer soaking time [26].

Both the "Solid" and "Sahala" lime samples are highly reactive at all soaking conditions $\left(\mathrm{R}_{\mathrm{DIN}}>30\right)$ as shown in Figure 5. However, the "Solid" lime samples are more reactive $\left(\mathrm{R}_{\mathrm{DIN}}=57-97\right)$ than the "Sahala" ones $\left(\mathrm{R}_{\mathrm{DIN}}=\right.$ $34-47)$. This is attributed to the relatively higher range of free lime content of the former samples (95\% - 97\%) as compared with that of the latter ones $(87 \%-95 \%)$. Also, preservation of the original ghost pores (OGP) of the parent limestone of the former samples as shown by SEM (Figure 6(a)) has contributed in increasing the limeparticles surface area and hence its reactivity [27].

The $\mathrm{R}_{\mathrm{DIN}}$-reactivity values of both the "Solid" and "Sahala" lime show a conspicuous decrease from 97 to 57 in the former and from 47 to 34 in the latter by increasing soaking time from $0.25 \mathrm{~h}$ to $2 \mathrm{~h}$, respectively. This could be attributed to the microfabric of the calcined lime as exhibited in (Figures 6(b)-(d)). The "Solid" lime at 0.25 $\mathrm{h}$ is characterized by very small lime crystallites (less than $2 \mu \mathrm{m}$ ) (Figure 6(b)), however their size is enlarged to be more than $(5 \mu \mathrm{m})$ at $2 \mathrm{~h}$ (Figure 6(c)). This is due to the crystallite grain growth at the longer soaking time [28,29].

On the other side, "Sahala" lime crystallites (Figure 6(d)) show grain growth micopores (GGM), which is the main cause for its higher reactivity. However, at $2 \mathrm{~h}$, the (GGM) are closed due to the formation of lime holo- and hemihedral-lime crystallites (HLC and HeLC, respectively) (Figure 6(e)), leading to lowering the reactivity of lime.

\section{Conclusions}

The "Solid" and "Sahala" ornamental stone wastes in Shak Al-Thoaban, Egypt are hazardous materials for the environment. Firing these wastes will eliminate their hazardous impact together with production of a useful

Table 1. Chemical composition of the technological waste samples.

\begin{tabular}{|c|c|c|c|c|c|c|c|c|c|c|c|c|c|}
\hline Sample & $\mathrm{CaO}$ & MgO & $\mathrm{SiO}_{2}$ & $\mathbf{A l}_{2} \mathbf{O}_{3}$ & $\mathrm{Fe}_{2} \mathrm{O}_{3}$ & $\mathrm{TiO}_{2}$ & $\mathbf{P}_{2} \mathbf{O}_{5}$ & MnO & $\mathrm{Na}_{2} \mathrm{O}$ & $\mathbf{K}_{2} \mathbf{O}$ & $\mathrm{SO}_{3}$ & Cl & L.O.I \\
\hline Solid & 55.61 & 0.11 & 0.16 & 0.03 & 0.11 & $<0.01$ & 0.04 & 0.01 & 0.02 & $<0.01$ & $<0.01$ & 0.03 & 43.70 \\
\hline Sahala & 54.85 & 0.13 & 0.48 & 0.08 & 0.09 & 0.02 & 0.03 & 0.00 & $<0.01$ & $<0.01$ & 1.05 & $<0.01$ & 43.09 \\
\hline
\end{tabular}

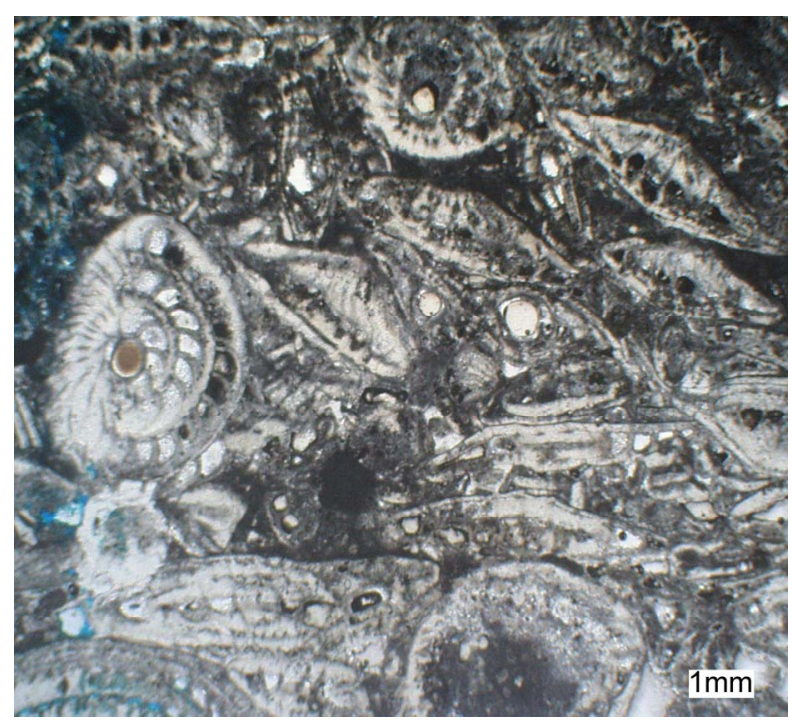

Figure 4. Grain-supported limestone enriched with fossils.

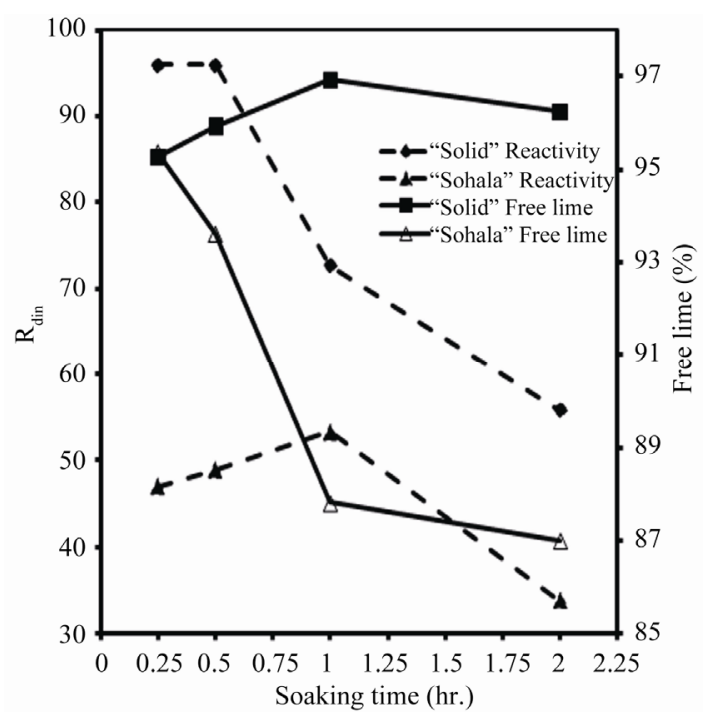

Figure 5. Free lime and hydration behavior of the lime samples. 

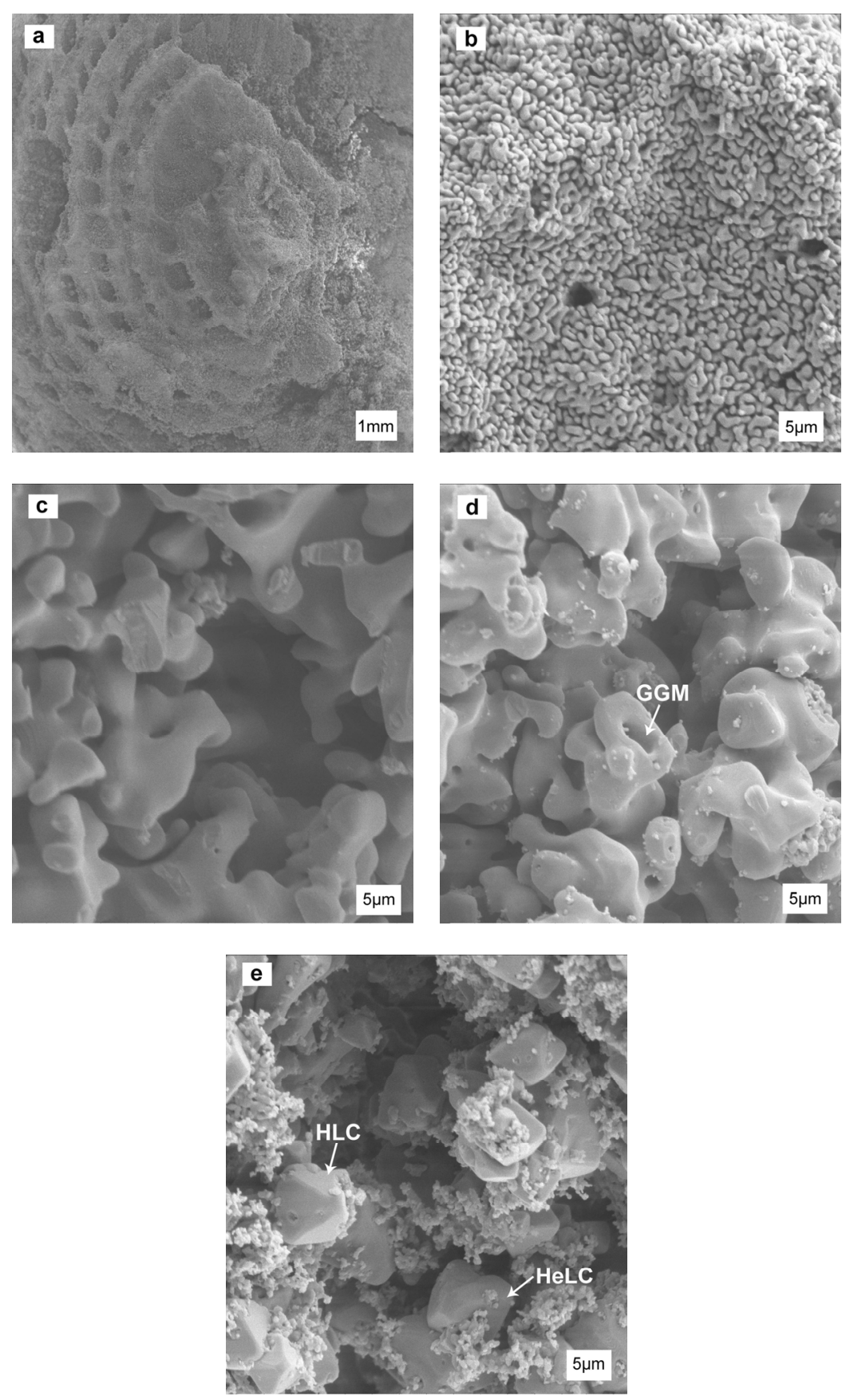

Figure 6. SEM micrographs of the lime samples under different conditions (a) The preservation of the original pores of the "Solid" lime at 0.25 and $2 \mathrm{~h}$; (b) "Solid" lime at $0.25 \mathrm{~h}$ with remnant fossil pores; (c) "Solid" lime at $2 \mathrm{~h}$; (d) "Sahala" lime at $1 \mathrm{~h}$ with GGM; (e) "Sahala" lime at $2 \mathrm{~h}$ with HeLC and HLC.

quick-lime product. The optimum firing conditions for producing highly reactive lime for the "Solid" and "Sahala" wastes are soaking for 0.25 and $1 \mathrm{~h}$ at $1000^{\circ} \mathrm{C}$, respectively.

\section{Acknowledgements}

The authors are grateful to Ain Shams university, Egypt for funding the research project: "Recycling of Shak AlThoaban wastes". The authors are also of deep gratitude to all the persons working in Shak Al-Thoaban area offered their sincere help, especially Haj Mahdy Abo-Zeid.

\section{REFERENCES}

[1] A. A. Dardir, A. K. Hassan and K. M. Abu Zeid, "Building 
and Construction Raw Materials in Egypt: An Overview," Proceeding of Geological Survey of Egypt. Cem. Conference, Cairo, 19-22 November1996, pp. 89-98.

[2] M. M. Hassaan, "The Economic Potential of the MesozoicCenozoic Carbonate Rocks in Egypt," Sedimentology of Egypt, Vol. 12, 2004, pp. 1-22.

[3] K. E. Alyamac and R. Ince, "A Preliminary Concrete Mix Design for SCC with Marble Powders," Construction and Building Materials, Vol. 23, No. 3, 2009, pp. 1201-1210. doi:10.1016/j.conbuildmat.2008.08.012

[4] G. Rego, C. Martínez, A. Quero, T. P. Blanco and J. M. Borquea, "The Effects of Dust Inhalation in Slate Industry Workers," Medicina Clinica, Vol. 116, No. 8, 2001, pp. 290-291.

[5] A. S. Reis, "Estudo do Aproveitamento do Resíduo de Beneficiamento de Resíduo de Rochas Ornamentais na Fabricac, ão de Ladrilho Hidráulico Piso Tátil," Master Dissertation, UFES-PPGEC, Vitória, 2008.

[6] H. Hebhoub, H. Aoun, M. Belachia, H. Houari and E. Ghorbel, "Use of Waste Marble Aggregates in Concrete," Construction and Building Materials, Vol. 23, No. 3, 2011, pp. 1167-1171. doi:10.1016/j.conbuildmat.2010.09.037

[7] S. N. Monteiro, L. A. Pecanha and C. M. F. Vieira, "Reformulation of Roofing Tiles Body with Addition of Granite Waste from Sawing Operations," Journal of the European Ceramic Society, Vol. 24, No. 8, 2004, pp. 23492356. doi:10.1016/S0955-2219(03)00638-1

[8] M. A. Monteiro, M. M. Jordan, M. B. Almendro-Candel, T. Senfeliu and M. S. Hernández-Crespo, "The Use of a Calcium Carbonate Residue from the Stone Industry in Manufacturing of Ceramic Tile Bodies," Applied Clay Science, Vol. 43, No. 2, 2009, pp. 186-189. doi:10.1016/j.clay.2008.08.003

[9] P. Torres, H. R. Fernandes, S. Agathopoulus, D. U. Tulyaganov and J. M. F. Ferreira, "Incorporation of Granite Cutting Sludge in Industrial Porcelain Tile Formulations," Journal of the European Ceramic Society, Vol. 24, No. 10-11, 2004, pp. 3177-3185.

doi:10.1016/j.jeurceramsoc.2003.10.039

[10] P. Torres, H. R. Fernandes, S. Olhero and J. M. F. Ferreira, "Incorporation of Wastes from Granite Rock Cutting and Polishing Industries to Produce Roof Tiles," Journal of the European Ceramic Society, Vol. 29, No. 1, 2009, pp. 2330. doi:10.1016/j.jeurceramsoc.2008.05.045

[11] A. J. Souza, B. C. A. Pinheiro and J. N. F. Holanda, "Processing of Floor Tiles Bearing Ornamental Rock-Cutting Waste," Journal of Materials Processing Technology, Vol. 210, No. 14, 2010, pp. 1898-1904. doi:10.1016/j.jmatprotec.2010.07.001

[12] A. J. Souza, B. C. A. Pinheiro and J. N. F. Holanda,. "Recycling of Gneiss Rock Waste in the Manufacture of Vitrified Floor Tiles," Journal of Environmental Management, Vol. 91, No. 3, 2010, pp. 685-689. doi:10.1016/j.jenvman.2009.09.032

[13] C. M. F. Vieira, T. M. Soares, R. Sánchez and S. N. Monteiro, "Incorporation of Granite Waste in Red Ceramics," Materials Science and Engineering: A, Vol. 373, No. 1-2,
2004, pp. 115-121. doi:10.1016/j.msea.2003.12.038

[14] R. M. Romualdo, S. F. Heber, A. N. Gelmires, L. L. de Helio and C. F. Heber, "Use of Granite Sawing Wastes in the Production of Ceramic Bricks and Tiles," Journal of the European Ceramic Society, Vol. 25, No. 7, 2005, pp. 1149-1158. doi:10.1016/j.jeurceramsoc.2004.04.020

[15] A. Wilson, A. V. Francisco and M. S. Ana, "Using Ornamental Stone Cutting Rejects as Raw Materials for Red Clay Ceramic Products: Properties and Microstructure Development," Materials Science and Engineering: A, Vol. 435, 2006, pp. 327-332. doi:10.1016/j.msea.2006.07.091

[16] J. M. S. Moreira, J. P. V. T. Manhaes and J. N. F. Holanda, "Processing of Red Ceramic Using Ornamental Rock Powder Waste," Journal of Materials Processing Technology, Vol. 196, No. 1-3, 2008, pp. 88-93. doi:10.1016/j.jmatprotec.2007.05.008

[17] P. Asokan, S. Mohini and R. A. Shyam, "Solid Wastes GeNeration in India and Their Recycling Potential in Building Materials," Building and Environment, Vol. 42, No. 6, 2007, pp. 2311-2320. doi:10.1016/j.buildenv.2006.04.015

[18] I. Mármol, P. Ballester, S. Cerro, G. Monros, J. Morales and L. Sanchez, "Use of Granite Sludge Wastes for the Production of Coloured Cement-Based Mortars," Cement and Concrete Composites, Vol. 32, No. 8, 2010, pp. 617622. doi:10.1016/j.cemconcomp.2010.06.003

[19] A. Nuno, B. Fernando and R. S. Jose, "Recycling of Stone Slurry in Industrial Activities: Application to Concrete Mixtures," Building and Environment, Vol. 42, No. 2, 2007, pp. 810-819. doi:10.1016/j.buildenv.2005.09.018

[20] A. M. Segadaesa, M. A. Carvalhob and W. Accharc, "Using Marble and Granite Rejects to Enhance the Processing of Clay Products," Applied Clay Science, Vol. 30, No. 1, 2005, pp. 42-52. doi:10.1016/i.clay.2005.03.004

[21] F. Saboya Jr., G. C. Xavier and J. Alexandre, "The Use of the Powder Marble Byproduct to Enhance the Properties of Brick Ceramic," Construction and Building Materials, Vol. 21, No. 10, 2007, pp. 1950-1960. doi:10.1016/j.conbuildmat.2006.05.029

[22] ASTM Standard C25-06, "Standard Test Methods for Chemical Analysis of Limestone, Quicklime and Hydrated Lime," ASTM International, West Conshohocken, 2006.

[23] J. H. Potgieter, S. S. Potgieter, S. S. Moja and A. MulabaBfubiandi, "The Standard Reactivity Test as a Measurement of Lime's Quality," Journal of the South African Institute of Mining and Metallurgy, Vol. 102, No. 1, 2002, pp. 67-69.

[24] R. C. Mackenzie, "Differential Thermal Analysis," Academic Press, London, Vol. 1, 1970.

[25] R. Boynton, "The Chemistry and Technology of Lime and Limestone," 2nd Edition, Wiley, New York, 1988.

[26] J. A. Oates, "Lime and Limestone: Chemistry and Technology, Production and Uses," Wiley-VCH, Weinheim, 1998.

[27] H. Kainer, E. Specht and R. Jascher, "Pore Diffusion, Reaction and Thermal Conduction Coefficients of Various Limestones and Their Influence on Decomposition Time," 
$Z K G$, Vol. 39, No. 5, 1986, pp. 259-268.

[28] W. D. Kingery, H. K. Bowen and D. R. Uhlmann, "Introduction to Ceramics," 2nd Edition, John Wiley and Sons, New York, 1976.
[29] R. Gotthardt, W. Dornap and H. Wilder, "Effect of Limestone Structure and Facies on the "R" Value as a Criterion of the Degree of Burning," ZKG International, Vol. 34, No. 8, 1981, pp. 424-429. 